\title{
The Peoples Inhabiting the Illyrian Provinces Known under the Name of Morlachs - Definition of the Ethnonym in the Light of the French Literature*
}

\author{
Ludność zamieszkujq̨ca Prowincje lliryjskie znana pod nazwq Morlacy- \\ definicja etnonimu w literaturze francuskiej
}

\section{STRESZCZENIE}

Artykuł stanowi analizę różnych przedstawień ludności określanej etnonimem Les Morlaques (Morlacy). Był on używany przez francuskich obserwatorów do opisania różnych populacji zamieszkujących Chorwację i Dalmację, które były częścią Prowincji Iliryjskich, istniejących w latach 1709-1713. Etnonim „Morlacy” pochodzi od greckiego wyrażenia oznaczającego „Czarnych Wołochów” (Mavro Vlasi), ale od XVI w. był używany nie tylko do opisywania Wołochów, ale również Słowian. Francuzi zapożyczyli stosowanie tego terminu od Włochów, chociaż od XVIII stulecia sami zaczęli badać Bałkany. Owe pierwsze próby skutkowały bardzo niespójną kartografią etniczną ludów bałkańskich, opartą na źródłach włoskich, niemieckich czy bizantyjskich. Owa niespójność jest możliwa do prześledzenia m.in. dzięki przestudiowaniu odpowiednich haseł w wydawnictwach encyklopedycznych. W związku z coraz większym politycznym zaangażowaniem Francji na Bałkanach i utworzeniem Prowincji Iliryjskich przez Napoleona, Francuzi zaczęli konkretyzować swoje wyobrażenia dotyczące ludów bałkańskich. Dotyczyło to również Morlaków, o których wypowiadali się m.in. tacy autorzy, jak Balthazar Hacquet czy Charles Nodier. W artykule starano się pokazać, w jaki sposób tożsamość Wołochów i Słowian, mieszkańców Prowincji Iliryjskich znanych pod nazwą Morlacy, zmieniała się w oczach zewnętrznego obserwatora. Problem ten jest istotny w kontekście szerszej perspektywy kształtowania się zachodnioeuropejskiego obrazu Bałkanów.

Słowa kluczowe: Prowincje Iliryjskie, Morlacy, Bałkany, francuskie oświecenie, ludy bałkańskie, stereotypy

* This article is a part of the research project "French image of the peoples inhabiting Illyrian Provinces" (National Science Centre, Poland, 2014/13/D/HS3/03701). 
The political presence of France in the Balkans was a very short episode - the Illyrian Provinces of the French Empire existed between 1809 and 1813. Even if the French military forces were present in the Balkans earlier (French army appeared in this region in $1806^{1}$ ), it is hard to compare this episode with the political and cultural impact of Venice and Habsburg Empire. However, this short period of French presence in South Eastern Europe is still worth to be analysed in the context of discussion on the rise and perception of the idea of the Balkans (led by such scholars as Maria Todorova or Paul Garde) $)^{2}$, and this debate would not be complete without it. The French influence on the image of the Balkans is worth our attention since French emphasised the necessity of gathering knowledge on the lands they governed, and they always put this rule into action ${ }^{3}$. The detailed description of the land and its inhabitants was especially important in the case of the Illyrian Provinces because they were very inconsistent creation in almost all dimensions. Their territory was inhabited by inhomogeneous population, who was speaking many languages, was influenced by different cultures and had different historical experiences ${ }^{4}$. Thus, an extensive knowledge was necessary to govern this land.

This knowledge, once gathered, often was published or was becoming a part of dictionaries and encyclopaedias. These kind of sources are extremely important because of their popularity. Already the case of Encyclopaedia of Diderot and d'Alembert proved that French writers and publishers knew how to attract the attention of the lecturers and shape the public opinion on wide spectre of problems, including the image of the different lands and their inhabitants ${ }^{5}$. The ability of merging of the different information from different sources into a coherent and attractive entity visible in the books issued by the French publishers also affected the Western European image of the part of Europe, which in $19^{\text {th }}$ century gradually began to be referred to as the "Balkans"6.

${ }^{1}$ M. Senkowska-Gluck, Rządy napoleońskie w Ilirii: 1809-1813, Wrocław 1980, pp. 16-19.

2 M. Todorova, Imagining the Balkans, Oxford-New York 2009; P. Garde, Le discours balkanique. Des mots et des hommes, Paris 2004, p. 40.

${ }^{3}$ M. Senkowska-Gluck, op. cit., p. 51.

${ }^{4}$ F. Bundy, The Administration of the Illyrian Provinces of the French Empire: 1809-1813, New York-London 1987, pp. 3-4.

${ }^{5}$ M. Pinault Sorensen, Encyclopédie, in: Dictionnaire européen des Lumières, ed. M. Delon, Paris 1997, pp. 453-456.

${ }^{6}$ In French literature this term was rarely used in favour of "Orient of Europe", which was applied by i.e. French journals during the Balkan wars (1912-1913) - W. Sajkowski, Pierwsza wojna bałkańska wedtug francuskiego dziennika "Le Temps", a zachodnioeuropejskie stereotypy dotyczące ludów bałkańskich, "Balcanica Posnaniensia" 2012, 19, pp. 231-240. 
This paper focuses on the problem of the French impact on the emergence of the idea of the Balkans on the example of the explanation of the ethnonym "Morlach" (Le Morlaque). According to many researchers, the confusion which concerns the meanings of the names of the toponyms and ethnonyms played an important role in the creation of the image of the Balkans (even the name of the Balkans is an example of such controversial nomenclature $)^{7}$.

The ethnonym "Morlachs" comes from Greek (Mavro Vlasi - the Black Vlachs), however, since the $16^{\text {th }}$ century has been used not only to describe Vlachs, but also Slavs, or even other groups. It was possible because Vlach pastors or military settlers merged with Slavs, and Venetians started to use the name "Morlachs" (Morlachci) towards all the people who were pastors like Vlachs regardless of the language they spoke or religion they prac-

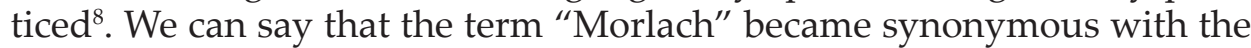
inhabitant of the Dalmatian province. Thus, it refers to many groups of Slavic or Romance origin leading pastoral and nomadic way of life, often military settlers guarding the border areas in Ottoman Turkey, Venice and the Habsburg Empire". These observations indicate that the term "Morlach" was used to omit ethnic and linguistic differences while taking into account the living conditions of communities. Its ambiguity and the capacity of information that it was able to bear makes it an example, which can represent the evolution of the perception of the Balkans in the end of the $18^{\text {th }}$ and the first half of the $19^{\text {th }}$ century.

The first point of the analysis of the French image of Morlachs is a problem of the definition of this name. We must emphasise that in the French sources from the second half of the $18^{\text {th }}$ century we find a very accurate definition. In 1749 Journal des Savants stated (while resuming Charles du Cange's publication Illyricum Vetus et Novum) that Dalmatia is inhabited by Morlaques, which means "Maurovlachi, that is to say the Latins Noirs. Those come from the Roman colonists, whom Trajan settled in Dacia near the Danube"10. The source of this explanation was most probably the work of one of the most important modern historians of Dalmatia and Croatia Ivan Lucićn ${ }^{11}$. The editors of the Encyclopédie méthodique from 1786 cited the German geographer Friedrich Anton Büsching, who stated that "the term

\footnotetext{
${ }^{7}$ P. Garde, op. cit., p. 40.

${ }^{8}$ W. Sajkowski, Obraz ludów bałkańskiego wybrzeża Adriatyku we Francji epoki Oświecenia, Poznań 2013, pp. 44-46.

9 J. Rapacka, Leksykon tradycji chorwackich, Warszawa 1997, p. 218.

${ }^{10}$ Caroli du Fresne, domini du Cange - Illyricum vetus et novum, "Le journal des savants pour l'année M.DCC.LIX" 1749, IX, p. 712.

${ }^{11}$ G. Lucio, Historia di Dalmatia: et in particolare delle città di Trav, Spalatro e Sebenico, Venetia 1674, p. 279.
} 
Morlach means, in essence, the Black Vlachs, but the Venetians mistakenly define with it the Slavic population"12. The latter definition, which reflect the relativity of this name, was however repressed from the French literature due to the great popularity of the work of Alberto Fortis, Viaggio in Dalmazia ${ }^{13}$. Fortis described the economy of Morlachs, which was based on grazing sheep and all the things that resulted from this way of life, including eating habits, or even their "national character" which - according to the traveller - was very similar to the pastoral peoples. The economy of Morlachs described by Fortis can be described as the economy characteristic for the Vlach shepherds - but at is was said before - the people practicing it were both of Vlach and Slavic origin, and thus Fortis had a serious problem while determining their identity.

This Italian traveller, who described Dalmatia and its inhabitants, stated that Morlachs are purely Slavic and do not have any Roman roots. In his opinion the word "Morlach" was composed of the two elements: more (originating from Slavic word more - the sea, because according to Fortis those people originated from the Black Sea coasts) and "vlah", which in his opinion meant "glorious" in Slavic language ${ }^{14}$. This belief was a reference to the conviction shared by European historiography of the $17^{\text {th }}$ and $18^{\text {th }}$ century that the name "Slavs" originated from Slavic word slava, which means glory, and thus Slavic means "glorious" or "famous"15. This conviction persisted in the $19^{\text {th }}$ century and was analysed by i.e. Adam Mickiewicz or Walerian Krasiński ${ }^{16}$. However, it is still not clear why Fortis proposed such explanation of the term "Morlachs". It is probable that as an Italian boasting of Roman origin he could not accept that a part of the people inhabiting Dalmatian province could also vaunt it. Ethnic map of Dalmatia reduced only to the Slavic element was easier to explain also in a historical perspective: the Roman heritage was identified with Italian culture, while Slavic world could be depicted as the legacy of the barbaric tribes that invaded Europe in late antiquity and early Medieval Ages.

${ }^{12}$ Morlaques, in: Encyclopédie méthodique, vol. 2: Géographie, ed. F. Robert, N. Masson de Morvilliers, Paris 1784, p. 406; A. F. Büsching, Nouveau traité de géographie, vol. 3, Paris 1769, p. 188.

${ }^{13}$ W. Sajkowski, Obraz ludów bałkańskiego wybrzeża Adriatyku we Francji epoki Oświecenia, pp.182-190.

${ }_{14}^{14}$ A. Fortis, Viaggio in Dalmazia, vol. 1, Venezia 1784, p. 47.

${ }^{15} \mathrm{C}$. Freschot, Memorie istoriche e geografiche della Dalmazia raccolte da D. Casimiro Freschot, benedettino, Bologna 1683, p. 18; A. Abbe, Histoire générale et particulière de Bohème, vol. 1, Prague 1783, p. 304.

${ }^{16}$ A. Mickiewicz, Pisma: Cours de littérature slave prof. au Collège de France, vol. 7, Paryż 1860, p. 122; V. Krasinski, Essai sur l'histoire religieuse des nations slaves: Trad. de l'anglais, Paris 1853, p. 2. 
This perspective was soon adapted by French literature and for many decades "Morlachs" were described not as Vlachs, but as the people of purely Slavic origin. Such was the case of Encyclopédie des voyages edited by Jacques Grasset de Saint- Saveur (1796) ${ }^{17}$ and Tableau des peuples qui habitent l'Europe by Frédéric Schoell (1810 and 1812), in which Morlachs were named as "Bulgars which live close to the sea"18. The use of the term "Bulgars" proves that Western historiography knew well the Byzantine sources, which noticed the existence of "Vlach" in Bulgaria and the close relations between Vlach and Bulgars ${ }^{19}$.

The most interesting explanation of the term "Morlachs" was given by Alexander Sapieha, Polish agent of Napoleon Bonaparte, who investigated world of the South Slavs for political reasons, visiting Croatia and Dalmatia with Alberto Fortis' book, which served him as a guide. In his opinion the term "Morlach" was composed of two words "More" - Slavic for the "sea" and "Lach" - which designed Slav². Thus, "Morlachs" were "Slavs of the Sea" and were closely related to Polish people - "Lachs" from "pole" - the latter word meaning "field" or "land" in Polish ${ }^{21}$.

The analysis of the French encyclopaedic sources proves that the explanation proposed by Alberto Fortis shaped the understanding of the term "Morlach", which even until the second half of the $19^{\text {th }}$ century could be associated purely with Slavs ${ }^{22}$. This presumption concerning the Slavic identity of Morlachs was also substantiated by the discovery of South Slavic folk culture, which was described by such terms as "Morlach poetry" or "Morlach dances".

However, the gradually raising interest of the French towards Dalmatia resulted in the coexistence between this and the former narration,

${ }^{17}$ Habitants de Morlaquie, in: Encyclopédie des voyages, contenant l'abrégé historique des mours, usages, habitudes domestiques, religion, fêtes, supplices, funérailles, sciences $\mathcal{E}$ arts, commerce de tous les peuples et la collection complète des costumes, civils, militaires, religieux, dignitaires de tous les peuples, dessinés d'après nature E gravés avec soin $\mathcal{E}$ coloriés à l'aquarelle, vol. 1, ed. J. Grasset de Saint-Saveur, Paris 1796, vol. 1.

${ }^{18}$ [...] Les Morlaques, c'est-à-dire Bulgares habitant sur les côtes de la mer [...] - F. Schoell, Tableau des peuples qui habitent l'Europe, classés d'après les langues qu'ils parlent, et tableau des religions qu'ils professent, Paris 1810, p. 37; idem, Tableau des peuples qui habitent l'Europe, classés d'après les langues qu'ils parlent, et tableau des religions qu'ils professent, Paris 1812, p. 79.

${ }^{19}$ N. Trifon, Les Aroumains. Un peuple qui s'en va, La Bussière 2005, p. 87.

20 "Lach" was really the name, which designated Poles - the descendants of the legendary Lech, the founder of Poland according to the $13^{\text {th }}$ century Wielkopolska chronicle.

${ }^{21}$ A. Sapieha, Podróże po krajach słowiańskich odbywane, Wrocław 1983, p. 30.

${ }^{22}$ W. Sajkowski, Morlacy w zachodnioeuropejskiej literaturze encyklopedycznej XVIII i XIX wieku. Recepcja dzieła Alberto Fortisa "Viaggio in Dalmazia", in: Stereotypy bałkańskie. Księga jubileuszowa Profesor Ilony Czamańskiej, eds. J. Paszkiewicz, Z. Pentek, Poznań 2011, pp. 131-143. 
which explained the etymology of the name "Morlachs" accurately. For example the readers of Géographie, Mathématique, Physique et Politique de Toutes les Parties du Monde published in 1803 could not only find the information about the real meaning of the name, but could also learn that it was assigned externally:

The Uskoks and Morlachs are without any doubt of the Vlach origin. The name Flak or Vlach, which is given to the Vlachs by all of their neighbours, despite the fact that they reject it, means 'the wandering shepherd', which fits well with the description of Dacians that is left by the ancient Roman authors ${ }^{23}$.

In this short passage Dalmatian Morlachs are associated not only with Vlachs, but also with the theory of Daco-Romanian origin of Roumanians (this name "Roumani" also figures in this publication).

Such was the state of knowledge on the meaning of the term "Morlach" right before the short, yet important episode, of the French presence in Dalmatia and Croatia. Did the episode of the French presence changed this state of affair? As it has been already mentioned, the gathering of the information on the lands and inhabitants of the Illyrian Provinces was one of the most important objectives of the French governors. According to Charles Nodier, French Romantic poet who was responsible for publishing Télégraphe officiel, the official journal of the Illyrian Provinces, and who was known as the promoter of the Slavic culture, stated that the French were able to "gather the great multitude of documents about the moral history of modern Illyria, which their predecessors were gathering only superficially" ${ }^{24}$. However, the analysis of the publications that were is-

${ }^{23}$ Les Uskoks et Morlaques sont incontestablement d'origine valaque. Le nom Flak ou Vlach, donné aux Valaques par tous leurs voisins, quoiqu'eux mêmes ils le rejettent, veut dire pasteur errant, ce qui s'accorde bien avec la description que nous ont laissé les auteurs romains des anciens Daces - Géographie Mathématique, Physique et Politique de Toutes les Parties du Monde, vol. 4, États de l'Autriche et de la Prusse, et des Appendices sur la Pologne et les Indemnité d'Allemagne, Paris 1803, p. 108.

${ }^{24}$ Quand le dernier gouvernement Français eut étendu sa puissance jusqu'aux limites de l'ancienne Grèce, et qu'il constitua en gouvernement provisoire, sous le nom d'Illyrie, les provinces d'Istrie, de Carniole, de Carinthie, de Croatie et de Dalmatie, en y joignant la république de Raguse, il y avoit très-peu de voyageurs en France et méme en Europe qui eussent poussé leurs recherches sur cette vieille terre où l'on supposoit à peine quelque reste de civilisation. Les événemens de la guerre et ceui de la politique ne tardèrent pas à y conduire une quantité considérable de Français, tantôt sous les drapeaux de l'armée, tantôt à la suite des adiministrations; et les loisirs d'une assez longue paix donnèrent à ceux qui étaient doués de quelque talent d'observation, tout le temps nécessaire pour le mettre en usage, et pour rassembler sur l'histoire morale del'Illyrie moderne une foule de documents que leurs prédécesseurs n'avaient pu recueillir qu'en courant-Ch. Nodier, Mélanges de littérature et de critique, vol. 2, Paris 1820, pp. 1-2. 
sued during or after the period of French reign in Illyria shows that the confusion which concerned the meaning of the name "Morlachs" was not gone.

Marcel de Serres in his Voyage en Autriche published in 1814 writes that Morlachs are Slavs and they are more precisely a part of the Serb population, along with Uskoks, Vlachs, Dalmatians, Montenegrins, Bosniaks, Istrians, and inhabitants of Kotor and Ragusa ${ }^{25}$. Very similar explanation (which also emphasised Slavic character of the Vlachs) was given by Tableau des peuples qui habitent l'Europe by Frédéric Schoell (editions from 1810 and 1812), which juxtaposed Morlachs with Bulgars or Bosniaks ${ }^{26}$. All of those nations were described as Slavs, but on the other hand, they were also described as "Illyrians". It is not clear if the latter term was a reference to ancient Illyrians since French historians questioned the theory of Mavro Orbini on the connection between Slavs and Illyrians already in the $18^{\text {th }}$ century ${ }^{27}$; however, it was surely suitable to describe the inhabitants of the Illyrian Provinces in a way that could indicate that some kind of ethnic entity existed.

The author of Tableau des peuples qui habitent l'Europe justified presumption on the Slavic identity of Morlachs on the basis of the ethnolinguistic arguments. The Serbian dialect of Slavic language "is spoken not only by the Servians, but also by Bosniaks, Bulgarians of today, who are called Vlachs by the Slavs, the Uskoks, the Morlachs (that is to sayBulgarians living on the shores of the Sea), the Slovenes (the only Slavic people, who preserved the original name of the nation), the Dalmatians, and the Ragusians" ${ }^{28}$. In this case not only the term "Morlachs", but also the term "Vlachs" was used in order to describe Bulgars who were listed as the Slavic people; however, the publication noticed that more precisely speaking "the ancient Bulgarians were Tatar people who arrived in the $5^{\text {th }}$ century from the Volga or Bolga; but successively they adapted the

${ }^{25}$ M. de Serres, Voyage en Autriche, ou essai statistique et géographique sur cet empire, vol. 4, Paris 1814, p. 378.

${ }^{26}$ F. Schoell, Tableau des peuples qui habitent l'Europe, Paris 1810, p. 37; idem, Tableau des peuples qui habitent l'Europe, Paris 1812, p. 79.

${ }^{27}$ W. Sajkowski, From Vinko Pribojevic to the French Encyclopaedia - the History of the South Slavs and the Historiography of the French Enlightenment, in: Colloquia Balcanica, vol. 2: Macedonia: Land, Region, Borderland, ed. J. Sujecka, Warszawa 2013, pp. 331-348.

${ }^{28}$ Le dialecte servien [...] est parlé non seulement par les Serviens, mais aussi par les Bosniaques, les Bulgares d'aujourd'hui, appelés Walaques par les Slaves, les Uscoques, les Morlaques (c'està-dire Bulgares habitant sur les côtes de la mer), les Esclavoniens (seul peuple slave qui ait conservé le nom originaire de la nation), les Dalmates et les Ragusais - F. Schoell, Tableau des peuples qui habitent l'Europe, classés d'après les langues qu'ils parlent, et tableau des religions qu'ils professent, Paris 1812, p. 79. 
language of Serbians simultaneously introducing several Tatar words" 29 . In this case, as in the majority of investigations on the Balkan peoples, French historiography relied on the Byzantine sources, which were extensively analysed by i.e. Charles du Cange ${ }^{30}$.

We must add that in French literature the term "Vlachs" was also defined more accurately. Annales des voyages de la géographie et de l'histoire from 1813 (which in this case was in fact citing Statistique du Royaume de Hongrie by Martin von Schwartner ${ }^{31}$ ) describe them as "the mixture of ancient Getes, Dacians and Romans with Bulgars and Slavs" ${ }^{\prime 32}$. However - as it can be seen on this example - the Slavic element in this definition is also strongly emphasised; this definition is more complex and tries to combine often contradictory information into one entity - thus, the ethno-genesis of Bulgars, Slavs and Roumanians was somehow merged into one.

The conviction that the term "Morlach" is synonymous with "Slav" was shared by Charles Nodier, who was seen as an expert in the area of Slavic literature ${ }^{33}$. In his article entitled Litterature Slave published on 4 February 1814 in "Journal de l'Empire" he writes about how the Slavic folk poetry is usually born: "This is usually during the first hours of the night when Morlach is walking up the mountainside and sings in monotonous, yet solemn, way the histories of the ancient Slavic barons" ${ }^{\prime 34}$. In fact this image was taken from the travel diary of Alberto Fortis ${ }^{35}$, but as it has been already mentioned, Nodier claimed that the French were incomparable when it came to gathering the information about Dalmatia or Croatia. He referred to a book which, according to him - is an exemplification of the French strive for knowledge. It is the book published in 1815 L'Illyrie et la

\section{${ }^{29}$ Ibidem.}

${ }^{30}$ W. Sajkowski, Obraz ludów bałkańskiego wybrzeża Adriatyku we Francji epoki Oświecenia, pp. 95-102; idem, From Vinko Pribojević to the French Encyclopaedia, pp. 338-342.

${ }^{31}$ M. von Schwartner, Statistique du Royaume de Hongrie, vol. 1, Francofort sur le Main 1813, pp. 71-72.

${ }^{32}$ Valaques se sont probablement formés par un mélange d'anciens Gètes, de Daces et de Romains, avec des Bulgares et des Slaves - Annales des voyages de la géographie et de l'histoire, vol. 21, transl. N. Wacken, Paris 1813, p. 378.

${ }^{33}$ M. Charles Nodier rapportait, il y a peu de mois, cette même histoire dans le "Journal des Débats", où il a donné d'excellents articles sur les Slaves - B. Hacquet, J. B. J. Breton de La Martinière, L'Illyrie et la Dalmatie ou mours, usages et costumes de leurs habitans et de ceux des contrées voisines, augmenté d'une mémoire sur la Croatie Militaire; orné de trente-deux planches, dont vingt-quatre d'après les gravures de l'ouvrage allemand, et huit d'après des dessins originaux inédits, vol. 2, Paris 1815, p. 19.

${ }^{34}$ C'est ordinairement après les premières heures du soir que le Morlaque se promène sur la montagne en racontant dans sou chant monotone, mais solennel, les exploits des anciens barons slaves. Il ne voit pas les ombres de ses pères dans les nuages, mais elles vivent partout autour de lui - Ch. Nodier, Littérature Slave, “Journal de l’Empire" 4 II 1814, p. 2.

${ }^{35}$ A. Fortis, op. cit., p. 91. 
Dalmatie, ou mours, coutumes et usages de leurs habitans by French traveller Balthazar Hacquet ${ }^{36}$, originally written in German, translated and considerably supplemented by Jean Baptiste Breton de La Martinière, who translated, edited and published books which described not only European geography (i.e. Spain, Portugal or Russia) ${ }^{37}$, but also such exotic lands as China, Japan, the Antilles or New Mexico ${ }^{38}$.

However, even in this book, described by Nodier as the most complete work on the people of Illyria, Morlachs are still described as purely Slavic tribe. The explanation of their identity becomes even more confusing since according to L'Illyrie et la Dalmatie, ou mours, coutumes et usages de leurs habitans "Morlachs, in 640 of the Christian era, during the reign of Emperor Heraclius, sent ambassadors to that monarch to obtain permission to become a part of the Eastern Empire" ${ }^{\prime 39}$. This ethno-genetic theory is of course an adaptation of the story on the arrival of the Croats to the coast of the Adriatic, which was described by Byzantine Emperor Constatine Porphyrogenetus and was later adapted by many Slavic historiographers, becoming vital element of the Croatian historical identity ${ }^{40}$. The appearance of the Croats near the Adriatic Sea in 640 was also a story known to the French literature. However, in the publication of Balthazar Hacquet and Jean Baptiste Breton the Croats were described as... the descendants of Morlachs ${ }^{41}$. Thus, the Morlachs were represented as a more ancient and

${ }^{36}$ Balthazar Hacquet was of French origin, however, he was in a military service of Habsburg Empire - I. Pederin, Njemački putopisi po Dalmaciji, Split 1989, pp. 14-15.

${ }^{37}$ J. B. J. Breton de La Martinière, L'Espagne et le Portugal ou mœurs, usages et costumes des habitans de ces royaumes, Paris 1815; idem, La Russie ou mours usages et costumes des habitans de toutes les provinces de cet Empire, Paris 1813.

${ }^{38}$ J. B. J. Breton de La Martinière, La Chine en miniature, ou choix de costumes, arts et métiers de cet Empire, représentés par 74 gravures, la plupart d'après les originaux inédits du cabinet de feu M. Bertin, ministre; accompagnés de notices explicatives historiques et littéraires, Paris 1811; idem, Le Japon, ou mœurs, usages et costumes des habitans de cet Empire, suivi de la relation du voyage et de la captivité du capitaine russe Golowin, Paris 1818; B. Edwards, Histoire de l'île Saint-Domingue, extraite de l'histoire civile et commerciale des Antilles, transl. J. B. J. Breton de La Martinière, Paris 1802; Z. M. Pike, Voyage au Nouveau-Mexique précédé d'une excursion aux sources du Missisipi, pendant les années 1805, 1806 et 1807, transl. J. B. J. Breton de La Martinière, Paris 1812.

${ }^{39}$ Cette peuplade illyrienne $n^{\prime}$ habite pas seulement un espace étroit sur la rive septentrionale du golfe Adriatique elle se trouve encore dans toute la haute Dalmatie. Les Morlaques, en l'an 640 de l'ère chrétienne, sous le règne de l'empereur Héraclius, envoyèrent des ambassadeurs ce monarque pour en obtenir la permission d faire partie de l'empire d'Orient - B. Hacquet, J. B. J. Breton de La Martinière, L'Illyrie et la Dalmatie ou mours, usages et costumes de leurs habitants, vol. 1, Paris 1815, p. 119.

${ }^{40}$ J. Rapacka, op. cit., pp. 145-148.

${ }^{41}$ B. Hacquet, J. B. J. Breton de La Martinière, L'Illyrie et la Dalmatie ou mœurs, usages et costumes de leurs habitans, vol. 1, p. 25. 
primitive Slavic nation than Croats. According to this publication Croats resided in highland Illyria (the term designating Croatia), while Morlachs resided in lower Illyria (which was the reference to Dalmatia or maybe also Istria and littoral Croatia) ${ }^{42}$.

In fact the ethnographical map of Illyria drawn in L'Illyrie et la Dalmatie, ou mours, coutumes et usages de leurs habitans was very complex. It also took into account such nations as Dalmatians, Uskoks, Serbs, Rascians and Likans (inhabitants of Lika). Some of them - like Croats, Likans or Dalmatians could be assigned to specific geographic region and their meaning was clearer, but such names as "Uskoks" (which for the authors of the publication was synonymous with Serbians) or "Morlachs" - were more semantically capacious.

Paradoxically, this ambiguity was sometimes helpful for an external observer. This semantic capacity of terms such as "Morlach" or "Uskok" helped to put in order the information about inhabitants of the Illyrian Provinces, for example when it came to the descriptions of the national character. In the $18^{\text {th }}$ century the character of Morlachs described in French literature consisted of contradictory elements. They could be portrayed as "good savages" who remained uncorrupted by civilisation and preserved the natural innocence of the primitive men. On the other hand, they could be depicted as descendants of the barbarians who were enemies of civilisation $^{43}$. This ambiguity was nothing exceptional when it came to modern anthropologic descriptions of peoples considered as uncivilised. However, in the book by Jean Baptiste Breton the positive traits of character presented in the $18^{\text {th }}$ century image of Morlachs were associated rather with Morlachs while the negative ones - with Uskoks ${ }^{44}$.

Relying on the above-mentioned printed publications, which were published during or after the French reign in Illyria, we conclude that the incorrect explanation of the term "Morlach" was persistent. The gathering of information on the inhabitants of the Illyrian Provinves complicated this issue sometimes. As it has been already mentioned, there existed the explanation of the word "Morlach" as "the black Vlachs" and the association with this term, but not of a certain nation but rather - the social group of shepherds. It was, however, repressed and Morlachs were considered as purely Slavic people.

\footnotetext{
${ }^{42}$ Ibidem, pp. 25-26.

${ }^{43}$ W. Sajkowski, Obraz ludów bałkańskiego wybrzeża Adriatyku we Francji epoki Oświecenia, pp. 157-219.

${ }^{44}$ B. Hacquet, J. B. J. Breton de La Martinière, L'Illyrie et la Dalmatie ou mœurs, usages et costumes de leurs habitans, vol. 1, pp. 121-122, vol. 2, pp. 37-38.
} 
One might ask why the known and existing explanation was repressed by the theory of purely Slavic nature of the Morlachs proposed by Alberto Fortis in 1774. Paradoxically, the discovery of Dalmatia and Croatia in the period of the existence of the Illyrian Provinces and the appearance of new information concerning their inhabitants not always clarified the doubts concerning their identity. The publishers who attended to compile the existing knowledge into one coherent entity tried to conciliate the theories on ethnic landscape of Croatia and Dalmatia that often appeared to be contradictory. The image of the Slavs transmitted by Western European historiography did not treat them as a cluster of different nations, but as one big nation divided in some sort of tribes, which were very similar to each other ${ }^{45}$. The other important key-notion is the conviction regarding the barbarian origin of the peoples inhabiting South Eastern Europe, which has been visible in French historiography since $18^{\text {th }}$ century ${ }^{46}$. The ethnic landscape of this part of Europe was not seen as a stable structure, but rather as a flexible configuration of various people who were the descendants of barbaric nomads and still preserved many elements of their nature.

The use of the term "Morlach" was getting increasingly weaker throughout the $19^{\text {th }}$ century. The emergence of the nation-state also in SouthEastern Europe resulted in an increasingly stronger use of such ethnonyms as Serbs, Croat or Romanian. The adjective "Morlach", which was previously associated with Slavic culture, was also starting to be repressed in favour of the mentioned terms, which are still in use today ${ }^{47}$.

\section{BIBLIOGRAPHY}

Abbe A., Histoire générale et particulière de Bohème, vol. 1, Prague 1783.

Annales des voyages de la géographie et de l'histoire, vol. 21, transl. N. Wacken, Paris 1813.

Breton de la Martinière J. B. J., La Chine en miniature, ou choix de costumes, arts et métiers de cet Empire, représentés par 74 gravures, la plupart d'après les originaux inédits du cabinet de feu M. Bertin, ministre; accompagnés de notices explicatives historiques et littéraires, Paris 1811. Breton de la Martinière J. B. J., La Russie ou mœurs usages et costumes des habitans de toutes les provinces de cet Empire, Paris 1813.

Breton de la Martinière J. B. J., Le Japon, ou mœurs, usages et costumes des habitans de cet Empire, suivi de la relation du voyage et de la captivité du capitaine russe Golowin, Paris 1818.

${ }^{45}$ L. Wolff, Inventing Eastern Europe. The Map of Civilisation on the Mind of the Enlightenment, Stanford 1994, pp. 284-331; W. Sajkowski, From Vinko Pribojević to the French Encyclopaedia, pp. 331-348.

${ }^{46}$ Ibidem.

${ }^{47}$ W. Sajkowski, Morlacy w zachodnioeuropejskiej literaturze encyklopedycznej XVIII i XIX wieku, pp. 141-143. 
Breton de la Martinière J. B. J., L'Espagne et le Portugal ou mœurs, usages et costumes des habitans de ces royaumes, Paris 1815.

Bundy F., The Administration of the Illyrian Provinces of the French Empire: 1809-1813, New York-London 1987.

Büsching A. F., Nouveau traité de géographie, vol. 3, Paris 1769.

Caroli du Fresne, domini du Cange - Illyricum vetus et novum, "Le journal des savants pour l'année M.DCC.LIX" 1749, IX .

Edwards B., Histoire de l'île Saint-Domingue, extraite de l'histoire civile et commerciale des Antilles, transl. J. B. J. Breton de La Martinière, Paris 1802.

Fortis A., Viaggio in Dalmazia, vol. 1, Venezia 1784.

Freschot C., Memorie istoriche e geografiche della Dalmazia raccolte da D. Casimiro Freschot, benedettino, Bologna 1683.

Garde P., Le discours balkanique. Des mots et des hommes, Paris 2004.

Géographie Mathématique, Physique et Politique de Toutes les Parties du Monde, vol. 4: États de l'Autriche et de la Prusse, et des Appendices sur la Pologne et les Indemnité d'Allemagne, Paris 1803.

Habitants de Morlaquie, in: Encyclopédie des voyages, contenant l'abrégé historique des mours, usages, habitudes domestiques, religion, fêtes, supplices, funérailles, sciences $\mathcal{E}$ arts, commerce de tous les peuples et la collection complète des costumes, civils, militaires, religieux, dignitaires de tous les peuples, dessinés d'après nature E gravés avec soin $\mathcal{E}$ coloriés à l'aquarelle, ed. Jacques Grasset de Saint-Saveur, vol. 1, Paris 1796.

Hacquet B., Breton de la Martinière J. B. J., L'Illyrie et la Dalmatie ou mœurs, usages et costumes de leurs habitants, vol. 1, Paris 1815.

Hacquet B., Breton de la Martinière J. B. J., L'Illyrie et la Dalmatie ou mœurs, usages et costumes de leurs habitans et de ceux des contrées voisines, augmenté d'une mémoire sur la Croatie Militaire; orné de trente-deux planches, dont vingt-quatre d'après les gravures de l'ouvrage allemand, et huit d'après des dessins originaux inédits, vol. 2, Paris 1815.

Krasinski V., Essai sur l'histoire religieuse des nations slaves: Trad. de l'anglais, Paris 1853.

Lucio G. Historia di Dalmatia: et in particolare delle città di Trav, Spalatro e Sebenico, Venetia 1674.

Mickiewicz A., Pisma: Cours de littérature slave prof. au Collège de France, vol. 7, Paryż 1860.

Morlaques, in: Encyclopédie méthodique, vol. 2: Géographie, ed. F. Robert, N. Masson de Morvilliers, Paris 1784.

Nodier Ch., Littérature slave, "Journal de l’Empire" 4 II 1814.

Nodier Ch., Mélanges de littérature et de critique, vol. 2, Paris 1820.

Pederin I., Njemački putopisi po Dalmaciji, Split 1989.

Pike Z. M., Voyage au Nouveau-Mexique précédé d'une excursion aux sources du Missisipi, pendant les années 1805, 1806 et 1807, transl. J. B. J. Breton de La Martinière, Paris 1812.

Pinault Sorensen M., Encyclopédie, in: Dictionnaire européen des Lumières, ed. M. Delon, Paris 1997.

Rapacka J., Leksykon tradycji chorwackich, Warszawa 1997.

Sajkowski W., From Vinko Pribojevic to the French Encyclopaedia - the History of the South Slavs and the Historiography of the French Enlightenment, in: Colloquia Balcanica, vol. 2: Macedonia: Land, Region, Borderland, ed. J. Sujecka, Warszawa 2013.

Sajkowski W., Morlacy w zachodnioeuropejskiej literaturze encyklopedycznej XVIII i XIX wieku. Recepcja dzieła Alberto Fortisa "Viaggio in Dalmazia" in: Stereotypy bałkańskie. Księga jubileuszowa Profesor Ilony Czamańskiej, ed. J. Paszkiewicz, Z. Pentek, Poznań 2011. 
Sajkowski W., Obraz ludów bałkańskiego wybrzeża Adriatyku we Francji epoki Oświecenia, Poznań 2013.

Sajkowski W., Pierwsza wojna bałkańska według francuskiego dziennika "Le Temps", a zachodnioeuropejskie stereotypy dotyczące ludów batkańskich, "Balcanica Posnaniensia" 2012, 19.

Sapieha A., Podróże po krajach słowiańskich odbywane, Wrocław 1983.

Schoell F., Tableau des peuples qui habitent l'Europe, classés d'après les langues qu'ils parlent, et tableau des religions qu'ils professent, Paris 1810.

Schoell F., Tableau des peuples qui habitent l'Europe, classés d'après les langues qu'ils parlent, et tableau des religions qu'ils professent, Paris 1812.

Schwartner M. von, Statistique du Royaume de Hongrie, vol. 1, Francofort sur le Main 1813.

Senkowska-Gluck M., Rządy napoleońskie w Ilirii: 1809-1813, Wrocław 1980.

Serres M. de, Voyage en Autriche, ou essai statistique et géographique sur cet empire, vol. 4, Paris 1814 .

Todorova M., Imagining the Balkans, Oxford-New York 2009.

Trifon N., Les Aroumains. Un peuple qui s'en va, La Bussière 2005.

Wolff L., Inventing Eastern Europe. The Map of Civilisation on the Mind of the Enlightenment, Stanford 1994.

\section{ABSTRACT}

The paper will analyse various representations of people called by an ethnonym Les Morlaques (Morlachs), which was used by French observers to describe various populations inhabiting Croatia and Dalmatia which were a part of the Illyrian Provinces (17091713). The ethnonym "Morlachs" comes from Greek (Mavro Vlasi - the Black Vlachs), however, since the $16^{\text {th }}$ century it was used not only to describe the Vlachs, but also the Slavs, or even other groups. French observers took over its use from the Italians, however, in the $18^{\text {th }}$ century they started to investigate the Balkan peoples by themselves. Those first attempts resulted in a very inconsistent ethnic cartography of the Balkan peoples, based mainly on the Byzantine, German and Italian testimonies. This inconsistence is visible especially thanks to the comparison between relevant articles in the encyclopaedic publications. However, within the rise of the French political interest in the Balkans and creation of the Illyrian Provinces by Napoleon, the French administrators started to concretize their image of the Balkan peoples. This concerned also Morlachs, who were described by the authors such as Balthasar Hacquet or Charles Nodier, and others. The paper will show how the identity of Vlachs and Slavs inhabiting Illyrian Provinces, known under the name of Morlachs, was changing in the eyes of the external observers. This problem is a part of a wider question of shaping the image of the Balkans by the western observers.

Key words: the Illyrian Provinces, Morlachs, the Balkans, French Enlightenment, Balkan peoples, stereotypes

\section{ABOUT AUTHOR}

Wojciech Sajkowski, PhD, Chair of the Balkan studies, Faculty of History, Adam Mickiewicz University in Poznan. He specialises in the creation of Western-European image of the Balkans and Eastern Europe in early modern era. Currently he is leading a research project "French image of the peoples inhabiting Illyrian Provinces", financed by National Science Centre of Poland. 